\title{
Correction to: From receptive profiles to a metric model of V1
}

\section{Noemi Montobbio ${ }^{1,2}$ (D) $\cdot$ Giovanna Citti ${ }^{1} \cdot$ Alessandro Sarti $^{2}$}

Published online: 14 September 2019

(C) Springer Science+Business Media, LLC, part of Springer Nature 2019

\section{Correction to: Journal of Computational Neuroscience (2019) 46:257-277 https://doi.org/10.1007/s10827-019-00716-6}

The authors would like to note an omission, in the published paper, of the Matlab code initially included as Electronic Supplementary Material. Therefore, we hereby resubmit the code in question.

Publisher's note Springer Nature remains neutral with regard to jurisdictional claims in published maps and institutional affiliations.

The online version of the original article can be found at https://doi.org/ 10.1007/s10827-019-00716-6

Electronic supplementary material The online version of this article (https://doi.org/10.1007/s10827-019-00728-2) contains supplementary material, which is available to authorized users.

\section{Noemi Montobbio}

noemi.montobbio2@unibo.it

1 Department of Mathematics, Università di Bologna, Bologna, Italy

2 CAMS Center of Mathematical Analysis (CNRS - EHESS),

Paris, France 